\title{
An Urgent Call to Make One Health Work for People and Our Planet
}

January 2020 begins a new decade, a chance for the international health community to take a hard look at where we are, where we stand, what we stand for and why we need to stand up. Staring us down are two concurrent global health emergencies: the coronavirus epidemic originating in Wuhan, China and climate change. As you read this, the trove of articles and assessments published on both is growing faster than most can absorb.

What does it all mean for us, as publicly engaged scientists? Like separate streams flowing into the more powerful ocean, several currents of thought and action are poised for the first time to mutually enhance their potential influence, for the sake of people and our planet. First is the well-established attention to social determinants of health matched by the multi-sector action-oriented 'health in all policies' approach, also reflected in the UN Agenda 2030 for Sustainable Development and its ambitious benchmarks.

Of note is that the 2030 Sustainable Development Goals (SDGs) were built on the underlying recognition that good health depends on integrated strategies; on cooperation not only between teams dedicated to different fields within health care and health promotion (mental health, maternal health, etc.), but between groups dedicated to causes integral to human health and wellbeing, such as the eradication and amelioration of poverty and the fight for climate justice.

This leads us to the second current: the public and scientific push to effectively address climate change, as the world hurtles along unsustainable, uneven and inequitable paths of consumption, emissions and economic/social development. More explicitly, nearly upon us are both the deadline for the 2030 SDGs and the point of no return for keeping global warming below the $2 \mathrm{~K}$ target.[1]

\section{The climate crisis is the game changer for One Health}

The climate crisis is in fact the game changer for the third current: One Health, a concept that traditionally has viewed human health through the lens of veterinary medicine, focusing primarily on zoonoses and food-borne diseases, with environmental concern as a less-prominent element. However, we agree with Paul Gibbs who argues that (while) "in the first decade of the One Health era, the concept provided the initiative, coordination, and drive to control and prevent disease in animals and people; now in the second decade, One Health needs to recognise the broader issue of Planetary Health..." [2] That is, when viewed synergistically with the more recent notion of Planetary Health (see the new journal in The Lancet family), One Health simply brings it all together, providing new momentum for interdisciplinary research and action.

To contribute to this movement, we have decided to expand the journal's purview to include research and perspectives on health in all policies and One Health in particular. In so doing, we extend a MEDICC Review invitation to scientists and professionals who focus on climate change; the links between environment and health; food security and poverty; disaster mitigation; health impact of economic/social injustice, conflict and crisis; human migration and demography; equality in access to health and health care; and all related endeavors of research and action. As always, MEDICC Review remains dedicated to our mission of incorporating and elevating voices and research from the Global South, from Latin America and the Caribbean in particular; those for whom these issues have hit, and will continue to hit, the hardest.

The One Health concept is a worldwide strategy for expanding interdisciplinary collaborations and communications in all aspects of health care for humans, animals and the environment.

-One Health Initiative

http://www.onehealthinitiative.com/about.php

Taking a look inside this issue: Much like the UN and climate researchers globally, WHO has agreed that 20202030 must be a "decade of action,"[3] and to that end has published a list of "urgent health challenges" for the next ten years.[4] Articles in this MEDICC Review tackle some of these.

Worldwide, access to WHO-defined "essential medicines"[5] medications necessary for treating conditions and disorders that primarily affect the world's poor-remains inadequate. A full third of the world's population lacks access to many of them, and for patients in developing countries who do, medicines represent $50 \%-90 \%$ of their out-of-pocket spending on health care.[5]

Cuba's burgeoning biotech industry has played a key role in increasing access to both novel medicines and biosimilars for Cuban and other patients in the Global South[6] and is poised to do so for years to come. Yet, as Blanco-García's article in this issue points out, reframing of global biotech's financial underpinnings is bound to present new challenges for Cuban biotechnology, which has thus far operated much on its own terms.

Investing in health equity means identifying those populations who are often left out of the conversation and understanding them well enough to address their needs in ways that acknowledge the relation between social and physical aspects of human health. In this context, the transition from working life to retirement can be precarious, and Cuba has one of the most rapidly-aging populations in Latin America and the Caribbean.[7] Ponce-Laguardia's paper describes the design and development of a community-wide (soon to be region-wide) program to help individuals prepare for and navigate this major life transition, putting emphasis on their mental health, social inclusion and overall wellbeing.

This year, as part of its "decade of action", WHO will issue new guidelines for health care providers and policymakers entitled 
Helping Adolescents Thrive. Among the issues addressed is the fact that teens worldwide are disproportionately affected by sexually-transmitted infections.[8] In this issue, we publish pioneering research that identifies the most prevalent HPV genotypes circulating among Cuban women. Guilarte-García and colleagues provide evidence supporting inclusion of an HPV vaccine into the public health system's national immunization program to help prevent cervical cancer, the fourth most frequent cancer and the fifth cause of cancer mortality in the female population.[9]

February 11 marks the International Day of Women and Girls in Science,[10] an excellent opportunity to draw attention to our regular column, Cuba's Women of Science. This time, we highlight the life and work of Dr Herminia Palenzuela, a founder of the Children's Heart Center at Havana's William Soler Pediatric University Hospital.
MEDICC Review also takes this opportunity to extend a warm welcome to $\mathrm{Dr}$ Caitlin Baird, a medical anthropologist and Mesoamericanist who has joined our team as Senior Editor, English Edition. Her experience, editorial skill and perspectives enrich us all.

And finally, we offer sincere gratitude to the scholars who provided peer reviews in 2019. Our work would not be possible without the generous donation of their time and effort.

We hope you will join us in tackling the challenges of the new decade-as readers, contributing authors, peer reviewers, in your letters to the editor, as interviewees, and as friends and colleagues. Decidedly, we are all in this together, and the "cost of doing nothing is one we cannot afford".[4] - 1 -

\section{The Editors}

1. Aengenheyster M, Feng QY, van der Ploeg F, Dijkstra HA. The point of no return for climate action: effects of climate uncertainty and risk tolerance. Earth Sys Dynam [Internet]. 2018 Aug 30 [cited 2020 Jan 25];9(3):1085-95. Available from: https://www.earth-syst-dynam.net/9/1085/2018/

2. Gibbs EPJ. Musings on the future direction of One Health, William Hunting and tuberculosis, while listening to blackbirds sing. Vec Rec [Internet]. 2018 Jul 14 [cited 2020 Jan 25];183(2):5762. Available from: https://veterinaryrecord.bmj .com/content/183/2/57.long

3. United Nations. SUSTAINABLE DEVELOPMENT GOALS [Internet]. New York: United Nations; c2020. Decade of action. Ten years to transform our world; 2020 Jan [cited 2020 Jan 25]; [about 1 screen]. Available from: https://www .un.org/sustainabledevelopment/decade-of-action/

4. World Health Organization [Internet]. Geneva: World Health Organization; c2020. Newsroom. Urgent health challenges for the next de- cade; 2020 Jan 13 [cited 2020 Jan 25]; [about 2 screens]. Available from: https://www.who .int/news-room/photo-story/photo-story-detail/ urgent-health-challenges-for-the-next-decade

5. World Health Organization [Internet]. Geneva: World Health Organization; c2020. News. Essential medicines and health products; [cited 2020 Jan 25]; [about 2 screens]. Available from: https:// www.who.int/medicines/news/2020/emergency -use-listing-procedure-and-roadmap-he/en/

6. Lage A. Connecting immunology research to public health: Cuban biotechnology. Nat Immunol [Internet]. 2008 Feb [cited 2020 Jan 25];9(2):109-12. Available from: https://www .nature.com/articles/ni0208-109

7. Cubadebate [Internet]. Havana: Cubadebate; c2014. Cuba en datos: ¿Cómo envejece la población cubana?; 2020 Jan 24 [cited 2020 Jan 25]; [about 15screens]. Available from: http:// www.cubadebate.cu/?s=como+envejece+la +poblacion+cubana. Spanish.
8. Center for Disease Control and Prevention (CDC) [Internet]. Atlanta: Center for Disease Control and Prevention (CDC); c2020. Sexually Transmitted Diseases (STDs). Life Stages and Populations. Adolecents and Young Adults; [updated 2017 Dec 7; cited 2020 Jan 25] Available from: https://www.cdc.gov/std/life -stages-populations/adolescents-youngadults htm

9. Ministry of Public Health (CU). Anuario Estadístico de Salud 2018 [Internet]. Havana: Ministry of Public Health (CU); 2019 Apr [cited 2020 Jan 25]. 206 p.Available from: http://files.sld.cu/bvscuba/ files/2019/04/Anuario-Electr\%C3\%B3nico-Espa \%C3\%B1ol-2018-ed-2019-compressed.pdf. Spanish

10. UNESCO [Internet]. Paris: UNESCO; c2020. Commemorations and Anniversaries; $2015 \mathrm{Dec}$ 22 [cited 2020 Jan 25]; [about 1 screen]. Available from: https://en.unesco.org/commemora tions/womenandgirlinscienceday 